\title{
LANGUAGE-IN-EDUCATION POLICIES AND INDIGENOUS LANGUAGE REVITALIZATION EFFORTS IN CANADA: CONSIDERATIONS FOR NON-DOMINANT LANGUAGE EDUCATION IN THE GLOBAL SOUTH
}

\author{
Onowa McIvor ${ }^{1}$ \\ University of Victoria, Canada \\ Jessica Ball \\ University of Victoria, Canada
}

\begin{abstract}
Indigenous languages are struggling for breath in the Global North. In Canada, Indigenous language medium schools and early childhood programs remain independent and marginalized. Despite government commitments, there is little support for Indigenous language-in-education policy and initiatives. This article describes an inaugural, countrywide, federally-funded, Indigenous-led language revitalization research project, entitled NETOLNEW_(one mind-one people). The project brings together nine Indigenous partners to build a country-wide network and momentum to pressure multi-levels of government to honour agreements enshrining the right of children to learn their Indigenous language. The project is documenting approaches to create new Indigenous language speakers, focusing on adult language learners able to keep the language vibrant and teach their language to children. The article reflects upon how this Northern emphasis on Indigenous language revitalization and country-wide networking initiative is relevant to mother tongue-based education and policy examples in the Global South. The article underscores the need for both community level initiatives (top-down) and government level policy and funding (bottom up) to support child and adult Indigenous language learning.
\end{abstract}

Keywords: Indigenous language practices, language-in-education policies, policy reform, First Nations, Indigenous, Canada, Global North, Global South

\footnotetext{
${ }^{1}$ Correspondence: Dr. Onowa McIvor, C/O Dept. of Indigenous Education, University of Victoria, PO Box 1700 STN CSC, Victoria BC V8W 2Y2; Email: omcivor@uvic.ca
} 


\section{$<^{n} \dot{\wedge} \Delta^{\supset}$ paspîwin - The act of successfully escaping or eluding danger ${ }^{2}$}

The 'last speaker of a dying language' makes a sensational news story, and the media and language advocacy efforts often draw attention more to language loss than to language recovery. Indeed, there is undeniable evidence of the endangerment of an estimated 3,000 Indigenous languages globally (UNESCO, 2017). Yet, there are many stories of gains being made to retain threatened and endangered languages and progress towards language recovery, giving reasons for hope and not only fear. In Canada, as elsewhere around the world, ethnolinguistic minority and Indigenous communities have been in a state of high alert about language erosion. However, it is also important to acknowledge that some languages have survived the multifarious forces driving them to the brink of extinction, and some are surviving against all odds. They are paspîwin - successfully escaping or eluding danger. These languages are typically the foundation and repository of culturally-based knowledge within communities who have had the awareness, will, leadership, and resources to mount a defense against threats to their language. Communities have done this by engaging in various forms of language retention and revitalization work. In both the global North and global South, this work has been done for centuries within small language enclaves. With expanding avenues for inter-community collaboration, this work has involved more broadly networked efforts involving the development of orthographies and programs for children and adults to see, hear and practice their language. In some cases, collaborative, community-led efforts have led to linkages with scholars in education and language revitalization. This article shares such efforts in Canada.

Some research has shown that, in Canada, the rate with which new Indigenous language speakers are being created is beginning to outpace the rate at which speakers are being lost (Dunlop, Gessner, Herbert, \& Parker, 2018; Statistics Canada, 2017a). This means that children, young people, and adults are actively engaged in learning their languages. Successful approaches that are contributing to this promising turn-around warrant investigation with a view toward lessons that could be shared. In Canada, language revitalization work is occurring in and by Indigenous communities themselves, and involves education across the lifespan with the goal of creating new language speakers or strengthening existing speakers of all ages. To date, communities in Canada have not benefitted enough from supportive government policies or investments. Yet, the survival and flourishing of the world's languages requires a 'wrap-around', systems-wide approach. A wrap-around approach means action at all levels, including: (1) top-down (community level) multigenerational programs; (2) mid-level (provincial/state/regional) enabling leadership, technical and financial support; and (3) bottom-up (high government level) enabling policies, advocacy, and strategic planning. In short, a strategically planned, multi-level effort is needed to fulfil children's rights and realize United Nations Sustainable Development Goal 4 which calls for signatories to "ensure inclusive and equitable equality education and promote lifelong learning opportunities for all” (United Nations General Assembly, 2015).

\section{The Canadian Context}

Momentum for non-dominant languages in education has burgeoned in the last two decades, with a growing number of reports on innovations and promising outcomes. Much of this effort has emanated from and reflects the Global South. Meanwhile, Indigenous

\footnotetext{
${ }^{2}$ Source: Alberta Elders' Cree Dictionary English-Cree (LeClaire \& Cardinal, 1998)
} 
languages remain marginalized in the Global North, and less attention has been paid to the challenges and promising practices experienced there. This article describes Indigenous language education and language policy in Canada. We also point to language policy and education environments in the Global South as points of comparison.

The focus of our work in Canada is specifically on Indigenous languages - that is the first languages of the lands now referred to as Canada, those of the peoples now referred to as First Nations, Inuit, and Metis. There are also many ethnic minority languages belonging to immigrant populations in Canada, including some that are also threatened or endangered in their homelands (Statistics Canada, 2011). However, our work and the project we highlight in this article involves the estimated 90 languages of Indigenous peoples in Canada (UNESCO, 2017). Herein we describe the rapidly evolving policy context and ongoing challenges of current language-in-education policy and implementation.

\section{Language revitalization in relation to mother tongue-based multilingual education}

Indigenous language-based education in Canada is referred to in terms of language revitalization or language maintenance. These terms are generally not part of the vocabulary of mother tongue-based education in the Global South. In some regions in both the Global North (i.e., Nunavut) and in many regions in the Global South, the home language, while non-dominant, is nevertheless healthy in terms of the numbers of proficient speakers and the use of the language in social life. Therefore, in these contexts in makes sense to focus on reforming language policy and on mother tongue-based (MTB) education. MTB education is directed towards enabling children to have a 'best' chance in school by conducting programs in their first language ('first language first'). In some cases, there is also a goal of enabling children to further develop their home language skills. Yet, there are also many communities in both the Global North and the Global South where the non-dominant language spoken in the home is extremely devalued in the wider society, and there may be few fully proficient speakers of the language (i.e., fully literate, or in Cummins' categorization, cognitivelyacademically proficient) (Cummins, 2000).

It can be difficult to find adults who are sufficiently proficient in the non-dominant language to be able to teach, especially beyond the early years, including literacy in the language. In Cambodia, for example, most of the Indigenous languages would be considered threatened on the EGID Scale (Lewis \& Simons, 2010). In most parts of Canada, except Nunavut in the far north, the status of nearly all Indigenous languages is more severe, with the vast majority of Indigenous children not speaking or hearing the Indigenous language at home. Therefore, policy, advocacy, and implementation are focused on revitalization approaches, including language immersion programs in which the 'mother-tongue' language used in the program is actually a new language for the children.

In this context for threatened-to-nearly extinct languages, there are unique challenges that make this a distinctive sub-field of non-dominant language education. In particular, there is an immediate priority on creating proficient adult speakers who can serve as teachers and who can also use the language functionally in social life, thereby sustaining its vitality. Hence, we argue for the use of the term language revitalization and draw attention to the specific challenges and strategies needed in these more extremely difficult circumstances. We also acknowledge that there are many similarities between the needs, goals, and strategies of language revitalization efforts and MTB education. Perhaps one crucial difference to highlight, however, is that language revitalization, as a field, encompasses efforts from cradle to grave to keep a language alive and developing, rather than 
a main focus on children's rights to learn in a language they already understand, which is the foundational goal of much MTB programming.

With this important differentiation in mind, we turn now to the landscape for Indigenous language revitalization in Canada, including a brief overview of grassroots efforts and government responsibilities and actions (and inaction) to date. We then describe the current, multi-year, government-funded project, NETOLNEW (name explained below), that is building momentum in the Indigenous language revitalization movement in Canada. Finally, we set this Northern example beside some points of similarity and difference with language learning and education environments in the Global South. We close with a formative conclusion and suggestions for action.

\section{Indigenous Language Education Policies in Canada}

Whether school is the best place to centre non-dominant language learning is controversial (Hornberger, 2008) and, regardless, the time allotted and technical and financial resources to ensure quality language learning opportunities are rarely enough. However, for many children the world over, a significant portion of their childhood is spent in a school setting, so it is a site that can have a decisive impact on whether and what language(s) children learn and the language proficiency they acquire. In Canada, historically, schools have been explicitly hostile to Indigenous language acquisition. The genocidal history of Canada has included the use of forced confinement of children in schools that forbade the use of Indigenous languages and produced the near extinction of most of Canada's Indigenous language wealth (Milloy, 1999).

As part of the Canadian government's efforts to atone for its historical legacies, commitments have been made to assist in the revitalization of Indigenous languages. However, these promises have not been kept; currently there is no federal plan or infrastructure to support the continuation or development of Indigenous languages, to fulfill children's right to learn their language, or adequately teach these languages in schools country-wide. Schools and early childhood programs with Indigenous languages as media of instruction are independent and remain marginalized within the larger education system. One of the reasons for this marginalization is because in Canada, education is under the jurisdiction of each of the ten provinces or three territories, yet, under the Indian Act (1985), services for Indigenous people fall under federal jurisdiction. The federal government is therefore legally responsible for the education of Indigenous students, including transferring funds to the provinces/territories for Indigenous students (Thorstenson, Hanna, \& Callison, 2006).

During the century of Indian residential schools, little Indigenous language use was permitted, in or outside the classroom. As Indian residential schools began to be phased out, schools on reserved lands were required to hire provincially-certified teachers and to teach the curriculum of the province in which they were located (McCue, 2011). In 1972, a group called the National Indian Brotherhood (now called the Assembly of First Nations) published the first Indigenous-authored treatise on education for Indigenous children entitled "Indian control of Indian Education" (National Indian Brotherhood, 1972). This was subsequently adopted as the unofficial education policy of the federal government regarding Indigenous children. While providing Indigenous communities with more authority over local education policies and programs, it has also been used by the federal government as a means to absolve itself of fiduciary responsibility for the education of Indigenous children (Bear Nicholas, 2001), while still requiring that Indigenous-operated schools use provincial curricula and meet provincial standards (Carr Stewart, 2006). While communities were gaining control 
over some aspects of their education, language was not overtly supported by this policy and the provincial/territorial requirements placed on communities made it difficult, if not impossible, to establish Indigenous language-medium schools during this era. Ball and McIvor explain,

over the past two decades, international movements for language revitalization and self-determination in education have become increasingly separate. This uncoupling of language and education policy is a common problem around the world that results in missed opportunities for language advocates and educators for mutually beneficial, coordinated efforts... (2013, p. 27)

Indigenous communities have continued to advocate for greater control over all aspects of their education, especially by creating independent school boards or negotiating legislation that provides autonomy over teacher certification and curriculum content (e.g., the First Nations Jurisdiction over Education in British Columbia Act, 2006). A rare example of a treaty recognizing full autonomy of an Indigenous people, including over education, in a nation-to-nation agreement, is the Nisga'a Final Agreement (2000). Yet, even in this progressive arrangement, restrictions continue to apply, including a requirement to prove equivalency with provincial education standards (Nisga'a Lisims Government, 1998). Lacking the necessary enabling policies, and supports, Indigenous communities across the country continue to struggle to implement fully autonomous education systems, which would provide control over certification, allocation of funds and resources, and curriculum content for Indigenous language medium education such as immersion and bilingual programs.

Some provinces and territories have legislation that recognizes the significance of Indigenous languages, and have education policies or policy frameworks to offer some provision for Indigenous students to learn their language to some extent. All provinces and territories allow for 'language as subject' programs where student demand and language teaching capacity exist. However, as MTB programming efforts elsewhere have also found, effort is often needed to create demand for the entire curriculum to be taught in non-dominant languages in contexts where this has not previously been an option. In Canada, outside of Indigenous communities themselves, there has been very little effort to raise awareness and create demand for learning an Indigenous language as a subject of study or as a medium of instruction. As well, with few exceptions, governments have not institutionalized teacher training in Indigenous languages, so that even where there may be enabling policy and willingness at a school level, there are rarely qualified teachers who are proficient in an Indigenous language available to teach in the language across all subjects. Thus, in almost all settings, there is scarce support to implement Indigenous language-medium immersion or bilingual programs that require fully certified professional teachers.

In short, even when there is enabling education policy, often there is a contradictory imposition of pre-existing restrictions on curriculum and learning outcomes imposed by provincial or territorial education requirements. For example, in 2007, the province of Ontario adopted a First Nations, Métis and Inuit Education Policy Framework aimed at improving education for Indigenous students, including access to Indigenous language learning support. Yet, mechanisms to implement the framework have never been articulated and provincial education requirements currently do not allow the use of languages other than the two official languages of English or French as the language of instruction outside of 
elective language classes. With the exception of two territories, no province provides specific support for Indigenous bilingual or immersion programs.

The two exceptions are the northern territories of Yukon and Nunavut. The territory of Nunavut leads the country in bilingual programming involving 86 per cent of Indigenous students (Statistics Canada, 2017b). Inuktitut and Inuinnaqtun are official languages in Nunavut alongside English and French. Developing these languages is one of four core curriculum strands in Nunavut's Department of Education (2007). All Nunavut schools offer bilingual programming (Indigenous language and another official language) from Kindergarten to Grade 3, and Indigenous languages must continue to be taught as a subject thereafter. The territory has a goal of bilingual education for all grades by 2020, though it is far from achieving this goal (Office of the Auditor General of Canada, 2013).

Another bright northern light in Canada is the Yukon Territory, where Indigenous language immersion programming is permitted and the Yukon Education Act requires teaching of Indigenous languages in Yukon schools. Yet, "[w]ith the exception of Tagish [an Indigenous language], all of the Yukon First Nations languages are being taught as second-language programs in 22 Yukon schools" (Yukon Schools, 2018).

Across all 10 provinces and three territories, barriers to creating Indigenous language programs include a lack of curricula, teaching and learning resources, and certified teachers who also speak the relevant Indigenous language (Richards \& Burnaby, 2008). There are also no technical resources in place, such as Indigenous language program guidelines, adequate widespread teacher training for Indigenous language pedagogy, or administrative support for the development and delivery of Indigenous language programs. McGregor, McIvor and Rosborough $(2017$; 2018) offer a rare example of a teacher training program focused on partnering with Indigenous communities to strengthen the language proficiency of prospective teachers while also providing professional education leading to permanent certification to teach across all subjects.

Successful Indigenous immersion programs are also exceedingly rare in Canada and are only found in land-based (on-reserve) communities (Fulford, 2007; McIvor \& McCarty, 2016) Examples include Mi'kmaw Kina'matnewey Eskasoni Mi'kmaw Immersion School in Nova Scotia (Gillies \& Battiste, 2013), Chief Atahm School for Secwepemc immersion in British Columbia (McIvor, 2005; Michel, 2012), and Karonhianónhnha Tsi Ionterihwaienstáhkhwa which is a Kanien'kéha (Mohawk language) immersion school located at Kahnawá:ke immersion in Québec (Kahnawá:ke Education Centre, 2019). These successes are the results of the hard work of the Indigenous communities who have innovated solutions despite lack of government support.

\section{Government Responsibilities}

Several legal commitments and declarations have been made by the Canadian government to Indigenous people in exchange for the land the settlers agreed to share and for the promise to live together in harmony and shared prosperity (Wabi, 2018). The original commitment covering most of the lands now referred to as Canada were numbered treaties which included provisions for schools on reserve. One example of this is Treaty 5 which states, "Her Majesty agrees to maintain schools for instruction in such reserves hereby made as to Her Government of the Dominion of Canada may seem advisable, whenever the Indians of the reserve shall desire it" (Treaty 5, 1969). Unfortunately, these promises were enacted through 'Her Majesty's designated government' (the colonial government of Canada) and were manifested in the form of the largely devastating Indian residential and day school system. These were operated mainly by religious organizations through contracts with the 
federal government, and Indigenous people had no opportunity to express their desire. Enrolment was enforced and parents who refused to give over their children to this system of assimilation were incarcerated. These institutions separated children from parents and grandparents, and siblings from one another, sometimes for a child's entire 10 to 12 years of schooling. They enforced foreign language learning while forbidding the use the mother tongue, requiring religious conversion. Many of these institutions were found to have sheltered pedophiles and other abusive caretakers. The schools left successive generations with deep wounds from familial separation, cultural and community displacement, shame and sadness, so that when children entered adulthood, they carried a heavy burden of losses and few of the treasures from their Indigenous birthright, including their language (see Legacy of Hope Foundation, 2014; Milloy, 1999; Truth and Reconciliation Commission of Canada, 2015).

Another important legislation affecting Indigenous people was the Canadian Constitution signed in 1982, which affirmed a legal obligation to the rights embedded in Treaties. According to Section 35.1 of the Canadian Constitution: "The existing aboriginal and treaty rights of the aboriginal peoples of Canada are hereby recognized and affirmed" (Canadian Charter of Rights and Freedoms, s. 35, 1983). The Constitution is important to education as it provides another legal structure to hold the government to account for their responsibilities to education by and for Indigenous peoples on their terms.

In 2015, a multi-year process was undertaken by a Truth and Reconciliation Commission to hear stories of Indian residential school experiences. The Commission produced a report for the Canadian government and its citizens that included 96 Calls to Action (Truth and Reconciliation Commission of Canada, 2015). Nine of these Calls pertain directly to language goals and several combine education goals. In 2016, the Canadian government made a commitment to enact all 96 Calls (Government of Canada, 2018). Also in 2016, the government signed the United Nations Declaration on the Rights of Indigenous Peoples (UNDRIP, 2007). This Declaration includes two main articles pertaining to language (Arts. 13, 14) including one combined with education: "Indigenous peoples have the right to establish and control their educational systems and institutions providing education in their own languages, in a manner appropriate to their cultural methods of teaching and learning." This article (14) is key in the necessary policy and program reforms moving forward.

In 2015, after a decade of a conservative government that was decidedly hostile towards Indigenous peoples, a more receptive government was elected. The new regime has made some promising contributions to language revitalization. The 2016 budget committed CDN\$2.6 billion over five years for First Nations elementary and secondary education, including CDN\$275 million to support First Nations language and culture (Indigenous Services Canada, 2019). However, the Parliamentary Budget Officer (Fréchette, 2016) found that this investment falls far short of what is needed to provide education services on par with non-Indigenous communities. The Office of the Auditor General of Canada (2018) found there was no clarity about how decisions are made for language and culture funding. While increased funding is an improvement, and regional policy frameworks express a commitment to better serve Indigenous students, neither are accompanied by clear strategies, concrete, time-bound, results-oriented actions, or designated actors to implement Indigenous bilingual and immersion programs that could measurably contribute to language revitalization and maintenance in Canada.

In 2017, the federal budget included $\mathrm{CDN} \$ 90$ million to help "preserve, protect and revitalize Indigenous languages and cultures" (Government of Canada, 2017). The government has also promised to pass an Indigenous Languages Act in 2019, in order to 
protect and continue Indigenous languages. Concurrently, the province of British Columbia is contributing CDN\$50 million over three years (2018-2021) towards language revival efforts in that province. Additionally, the Social Sciences and Research Council of Canada, the main agency distributing federal funds for social science research, has dedicated a funding stream specifically for Indigenous research, including language revitalization studies, and is currently funding the NETOLNEW_ project described subsequently. These are promising, long-awaited gestures. Much more is needed, over a sustained period, to realize the goal of retaining the many Indigenous language threatened or on the brink of extinction. But they offer hope to Indigenous communities that have never lost their love for their languages and their recognition of the value they hold for retaining cultural knowledge, worldviews, and connections among people, the land, and the universe.

\section{NETOLNEW: An Indigenous-led, country-wide capacity strengthening initiative}

The education and language policy context described highlights how Indigenous desire for Indigenous language learning in education has inspired some successful programs and, in two territories, produced government-level policy to support efforts. Yet, Indigenous aspirations and community-led efforts for language retention and revitalization have been pervasively thwarted by lack of policy, conciliatory gestures without adequate funding, within authoritarian strategies, policy without action, contradictory provincial educational requirements, and lack of investment in strengthening the technical capacity to deliver quality programming.

Recognizing the historical and persisting hostile environment for Indigenous languages, and the grim predictions for most Indigenous languages in Canada, a group of Indigenous educators, language activists, scholars, and non-Indigenous allies from across Canada came together in 2016 to engage in positive action through a research project. The project includes nine Indigenous community and organizational partners from across Canada. The first author of this article is one of two Indigenous co-directors; the second author is a co-leader. Through $\mathrm{CDN} \$ 2.5$ million in federal research funding received in 2017, this Indigenous-led project commenced under the name NETOLNEW, a SENĆOFEN language word meaning "one mind, one people" (www.netolnew.ca).

The name is significant because there are believed to be approximately 90 Indigenous languages in Canada, and diversity can sometimes be a barrier to coordinated action towards unified goals. The name signifies the spirit of collaboration and unity towards the goal of Indigenous language revitalization and maintenance, embracing the diversity of languages across distinctive Indigenous communities and cultures. An important aspect of the partnership is that it is Indigenous-led and governed. The overall goals of the project are to share knowledge, document successful language programs, strengthen leadership capacity, and create political pressure to create enabling federal, provincial and territorial polices that provide meaningful support for Indigenous language retention, revitalization and recovery.

The project partners appreciate that efforts in Indigenous language revitalization largely consist of the important work of documenting Elder speakers, curriculum development, and preschool and school-based programs. Yet, adult language learning is being largely ignored. The partners agree that supporting Indigenous adults to learn their Indigenous language, or to enhance their proficiency in their language, is critical for several reasons. Most importantly, adult speakers can introduce or maintain the language in their homes and as a functional language in their social and economic life. Adult speakers can also support their children's learning both at home and when children have opportunities to learn their language in school. Without adult speakers, there are no languages in homes or teachers 
in early childhood programs and schools. Hence, the partnership has an adult learner focus, with a view to the prospective roles of adult speakers as future teachers, curriculum developers, administrators in immersion schools, and leaders of the language revitalization movement. The central focus of the research is documenting promising adult education practices for producing adult Indigenous language speakers. As well, a long-term goal is to build upon this inaugural country-wide partnership to create a full-fledged, sustainable, national network to share language learning innovations and their outcomes, and thereby provide political advocacy towards policy reform.

This networked program of research is distributed across five themes shown in Figure 1 housed under the roof (of Adult Indigenous Language Learning) in the shape of a longhouse, which is traditional to the Indigenous peoples along the west coast of Canada.

Figure 1. Five research themes to explore adult Indigenous language learning

\section{ONE mind - ONE people \\ NEFOLNEE}

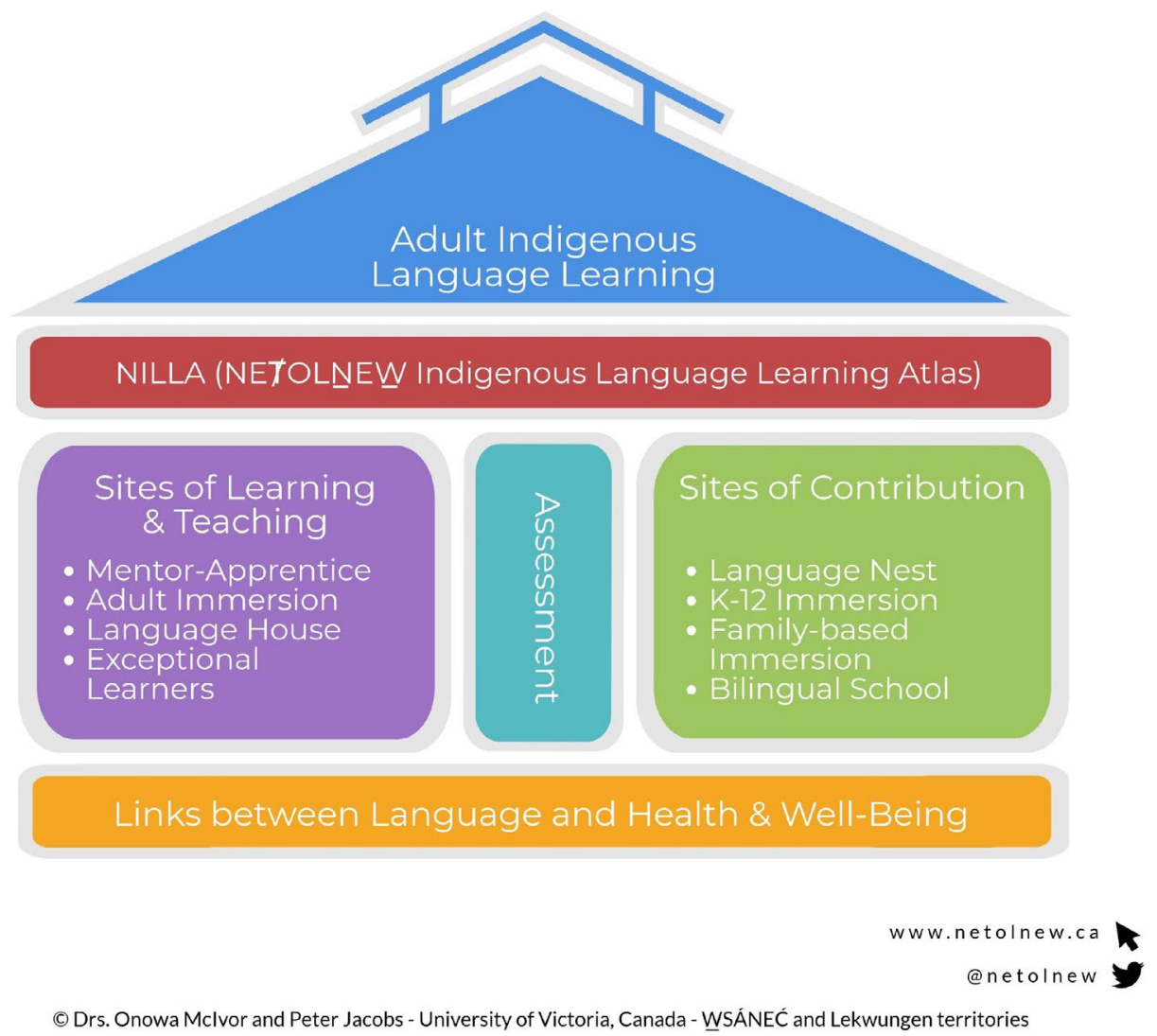

(C) Drs. Onowa Mclvor and Peter Jacobs - University of Victoria, Canada - ẂSÁNEĆ and Lekwungen territories

Theme 1: NILLA (NETOLNEW_ Indigenous Language Learning Atlas). This theme, subsequently explained in more detail, is highlighted in this article. The outcome will be an interactive, online atlas (multi-layered, searchable portal) of language retention and 
revitalization activity across Canada and a source of knowledge about various types of Indigenous language revitalization projects and approaches. Community and partner feedback has led the atlas development also to include spaces for community-to-community interaction, sharing resources and learning and teaching techniques.

Theme 2: Language-learning Assessment Tool. Community-based Indigenous language specialists have long since recognized that most language learning assessment tools were inadequate and lacked important nuances to the cultural and contextual aspects of their work. This theme supports the development of relevant language learning assessment tools in Indigenous communities that are also based on rigorous additional language learning science, and tools will be pilot-tested these within partner communities. The project also involves the same sharing and continuity sentiments of the overall research project for maximum benefit between communities while also respecting autonomy.

Theme 3: Sites of Adult Indigenous Language Learning and Teaching. Partner communities' primary goal is to advance proficiency among adult language learners and speakers, which will create and strengthen speakers across generations. Research underway within this theme is yielding insights into various innovative adult Indigenous language learning models towards advancing proficiency in the various languages.

Theme 4: Sites of Contribution. Adult Indigenous language learners are regularly called upon to pass on the language to others, while continuing to learn their language themselves. This part of the project explores the impacts of the work that adult speakers do with other learners, including children and youth in their communities.

Theme 5: Health and well-being. Studies suggest that language use is correlated with particular health outcomes for Indigenous people. The project is investigating the ways that learners' wellness is affected by their involvement in language learning and teaching, as well as the ways their efforts contribute to the overall wellness of their communities.

\section{Indigenous Language Learning Atlas}

Theme 1, the NETOLNEW_ Indigenous Language Learning Atlas (NILLA), is especially pertinent to the current discussion. It is an online, interactive portal created for the primary purpose of information sharing amongst Indigenous language communities and secondarily providing opportunities for the general public to learn more about language revitalization goals, efforts, and successes in Canada.

NILLA extends the idea of relational networking using technologies that enable: (1) sharing among and between Indigenous entities and development of a national network of language revitalization communities; (2) mapping and documenting existing Indigenous language learning efforts; (3) the sharing and development of pedagogical and practical tools that enable language continuation; (4) a collection of policy measures and collective advocacy for advancing Indigenous language learning; and (5) the creation of a national repository for research that can be accessed and utilized primarily for the benefit of communities engaged in language revitalization work but also used to inform national and international governments and researchers.

Historically, the Indigenous language revitalization movement was borne of individual community activities and later efforts to travel and learn from one another. In more recent times, language gatherings and conferences have leveraged the field to expand 
and accelerate the shared learning between communities and researchers. Maintaining these connections beyond the conference experience is a bigger challenge, as is developing and supporting connections for individuals and communities who may not attend such gatherings. The NILLA portal transfers the Indigenous Language Revitalization spirit of connecting, exchanging, and engaging to the virtual realm, rather than relying solely on inperson meetings, for communities to connect without the time away from community and expense of travel. It also allows for real time sharing as developments occur rather than once or twice a year via abstracts that are developed for conference submission the year prior.

The NILLA project tackles two practical circumstances of Indigenous languages in Canada: an exceptionally rich language diversity, and the vast geographic reality of these languages. While this virtual space will help to close these gaps and promote connection, these same, often isolated or excluded communities will need to be reached, to learn about the portal and the opportunities to connect virtually. This outreach and engagement are key endeavours within this theme. Beyond the initial technical development and implementation phase, now underway, the work will also focus on bringing NILLA to life through community connection. The success of the portal depends upon communities choosing to share their language contexts and accessing the portal to find and exchange knowledge with others: no community information will be included within the portal without explicit community-level permission. The overall goal of NILLA is to ensure its meaning and utility by engaging farflung and wide-ranging Indigenous communities, language organizations, academic institutions, and allied political bodies. In this way, NILLA will contribute to the overall NETOLNEW_project, promoting community and academic connections, research, education and language training by and for Indigenous people.

\section{Sharing insights and approaches with the Global South}

The foregoing description of language revitalization efforts within the Canadian context suggests some points of clarification, cautionary notes, and inspiration that may be useful for consideration in certain contexts in the Global South. There are points of similarity and difference between Canada and settings in the Global South where languages are threatened that are worth exploring. This exploration serves to deepen and broaden our understanding of the challenges and avenues for ensuring that languages and the people to whom they belong flourish.

First, like many settings in the Global South, Canada has a great diversity of Indigenous languages and dialects. This creates challenges for a country-wide approach to language retention. In small countries with fewer languages, such as Aotearoa/New Zealand, a decision was taken to choose one language and one variety of that language to champion and promulgate in education. This decision is a political, social and cultural impossibility in a geographically vast and linguistically diverse country such as Canada, as it is in many other countries around the globe. Yet, where national government support is needed to legislate and fund Indigenous language education, a highly fragmented, exclusively communityfocused orientation to language survival is likely to fail to gather sufficient resources to succeed. The NETOLNEW_project was conceived out of this recognition: a country-wide network of Indigenous partners and allies, led by Indigenous language champions, will assist in building a national collaborative agenda for knowing, sharing and gathering strength from across language groups and communities. These collaborations can also put political pressure on governments to be accountable to their legal responsibilities, domestic commitments and international declarations regarding Indigenous language rights. Together we stand to retain Indigenous languages; divided we are likely doomed to fail. In many linguistically - 
diverse countries in the Global South, there are strong grassroots efforts in small language enclaves, but these communities and their language leaders are often not connected with other communities and leaders. Some are in heated arguments over language issues with nearby peoples. This isolation can allow governments to elide their responsibilities, allowing communities to expend limited time and resources trying to maintain their languages through boot-strapped efforts and in disputes over linguistic differences, leaving little or no time and resources for unified action to exert pressure on government to support language retention.

Second, in Canada, and around the globe, grassroots efforts have overwhelmingly focused on children's acquisition of the Indigenous (or ethno-linguistic minority) language. Yet, in contexts where languages are rapidly eroding, there are typically few adults who are fully proficient in their Indigenous language. Impetus for the NETOLNEW_project was provided by growing recognition among Indigenous language leaders that this child-focused approach ignores a huge gap. It is widely accepted that the most important determinant of the quality of education is the quality of the teaching. Without language proficient adults who are skilled in teaching children in the language (as the medium of instruction), there is an assured deficit in the quality of program delivery that will manifest in disappointing outcomes. Investment in adults' language learning is a prerequisite for successful Indigenous language-based education. Yet, in the Global South, there is more investment of financial and technical resources in expanding mother tongue-based education in primary school than there is in formal and non-formal education to produce adult language speakers and teachers or to enhance adults' speaking, reading and writing in the non-dominant language.

Third, Canada lacks the enabling policy provisions that are now moving into place in a growing number of countries or regional entities in the Global South. For example, the multilingual policies of Singapore (Goh et al., 1979; Platt, 1982), the Philippines (2009, 2013), and more recently the Royal Government of Cambodia (2015) which supports five Indigenous languages in five provinces, are all examples that the government of Canada could and, legislatively, should aspire towards ${ }^{3}$.

Finally, and most importantly, from a global perspective, Canada could be considered a forerunner in recognizing the distinct language context and current circumstance while working collaboratively with Indigenous communities towards recognition and action (Government of Canada, 2019). While Statistics Canada (2017a) reports all but three Indigenous languages are poised for extinction, contemporary Indigenous leaders in language revitalization advocacy work assert that no Indigenous languages in Canada are safe (Assembly of First Nations, 2019; Cardwell, 2010). Due to the small number of adult speakers in most communities, very few Indigenous youngsters in Canada are learning their Indigenous language as a 'first language' in their homes, resulting in school as the site that often creates communicative continuation in Indigenous languages. Therefore, Indigenous language immersion and bilingual programs for children in Canada generally require children to transition from English or French (at home) to a new language when they arrive at school.

As elsewhere in the North and South, the work of Indigenous language revitalization described in this article began of necessity due to linguistic and other acts of genocide perpetrated by the colonial government in Canada (Ball \& McIvor, 2013; McIvor \& McCarty,

\footnotetext{
${ }^{3}$ The authors note that at the time of publication, Canada had set forth its first ever Indigenous Languages Act. However, it had not yet passed, and if it is successful in moving through parliament, the implementation and impacts will not be fully known for some time.
} 
2016). It is not yet clear whether Indigenous language revitalization in formal and non-formal education is an entirely separate field of endeavour from the field of mother tongue-based education, or a sub-field of non-dominant language education more generally (Hobson, Lowe, Poetsch \&Walsh, 2010; Zuckerman, 2019). However, it is clear that this is a meaningful and useful distinction. There are Indigenous language populations in the Global South that face similar circumstances of extremely attenuated language proficiency. These language situations warrant a distinctive approach, including one that invests in adult language learning in equal measure to child language learning, and that accepts that children entering a 'mother tongue-based' learning environment may not have acquired much, or any, 'mother tongue' before arriving at a 'mother tongue-based' program. As we have found in Canada, in these situations, extra effort may be needed to create demand for Indigenous language learning in school, because most parents understandably want their children to go to school in a language they know (a foundational argument for mother tongue-based education). Parents may fear they cannot support their children's learning because they are not fluent or literate in their heritage language themselves, and they may have internalized societal stigma against their heritage language.

\section{Conclusion}

There is a wide range of language characteristics and broader policy contexts in communities where non-dominant languages have flourished. This diversity calls for distinctive approaches to education that is designed to promote acquisition of non-dominant languages. This article has focused on Indigenous language contexts in Canada where historic government policies have pushed languages to the brink of extinction and where existing education policies are hindering current language recovery efforts. While our central example is situated in Canada, endangered languages exist in hostile policy contexts around the world. We have described an Indigenous-led, networked research and action initiative that brings together diverse language communities across a geographically vast Canada with diverse linguistic and political regions. Our purpose is to create a unified, Indigenous language-focused civil society movement to gather and mobilize evidence of effective language learning programs, and to exert pressure on government to create and fulfill legislative and policy commitments towards Indigenous language rights in education and public life. In Canada, as elsewhere, community-led efforts have managed to keep languages alive against all odds. They are paspîwin - successfully escaping or eluding danger. However, with increasing realities of urbanization, in-migration of diverse language speakers into formerly isolated communities, and globalization, "smaller" non-dominant language communities are increasingly hard-pressed to 'go it alone.' In Canada, there is currently no formal infrastructure to support the creation and maintenance of Indigenous language education programs countrywide. Yet, we have seen international examples where the combination of government policy and financial and technical resources can both create and support the implementation of policy and infrastructure needed to support community-level efforts. Canada lacks the language-in-education policies found in a growing number of countries and sub-national states in the Global South, but the current NETOLNEW_project is paving a promising pathway to Indigenous-led, unified action to harness the topdown/bottom-up synergy needed to assure that people's own languages flourish for generations to come. 


\section{References}

Assembly of First Nations. (2019, February 1). AFN National Chief Perry Bellegarde addresses UN General Assembly at launch event for the international year of Indigenous Languages. Assembly of First Nations News. Retrieved from https://www.afn.ca/2019/02/01/afn-national-chief-perry-bellegarde-addresses-ungeneral-assembly-at-launch-event-for-the-international-year-of-indigenous-languagesand-calls-for-support-for-upcoming-indigenous-languages-legislation/

Ball, J., \& McIvor, O. (2013). Canada's big chill. In C. Benson \& K. Kosonen (Eds.), Language Issues in Comparative Education (pp. 19-38). Rotterdam, the Netherlands: Sense.

Bear Nicholas, A. (2001). Canada's colonial mission: The great white bird. In K. P. Binda \& S. Calliou (Eds.), Aboriginal education in Canada: A study in decolonization (pp. 9-34). Mississauga, ON: Canadian Educators' Press.

Canadian charter of rights and freedoms, s. 35, Part I of the Constitution Act, 1982, being Schedule B to the Canada Act 1982 (UK), 1982, c 11 (1983).

Cardwell, M. (2010). Fight to revitalize Canada's Indigenous languages. University Affairs, $51(10), 12-17$.

Carr Stewart, S. (2006). First Nations education: Financial accountability and educational attainment. Canadian Journal of Education/Revue Canadienne de l'éducation, 29(4), 9981018.

Cummins, J. (2000). Language, power and pedagogy: Bilingual children in the crossfire. (C. Baker $\&$ N. Hornberger, Eds.). Toronto, ON: Multilingual Matters Ltd.

Dunlop, B., Gessner, S., Herbert, T., \& Parker, A. (2018). Report on the status of B.C. First Nations languages. Brentwood Bay, BC: First Peoples' Cultural Council (FPCC). Retrieved from http://www.fpcc.ca/language/status-report/

First Nations Jurisdiction over Education in British Columbia / Act Loi sur la compétence des premières nations en matière d'éducation en Colombie- Britannique, S.C. 2006, c. 10 (2007). Retrieved from https://laws-lois.justice.gc.ca/eng/acts/F-1 1.75/page1.html

Fréchette, J.-D. (2016). Federal spending on primary and secondary education on First Nations reserves. Retrieved from https://www.pbodpb.gc.ca/web/default/files/files/files/Publications/First_Nations_Education_EN.pdf

Fulford, G. (2007). Sharing our success: More case studies in Aboriginal schooling. Kelowna, BC: Society for the Advancement of Excellence in Education.

Gillies, C., \& Battiste, M. (2013). First Nations, Métis, and Inuit K-12 language programming: What works? In K. Arnett \& C. Mady (Eds.), Minority Populations in Second Language Education: Broadening the Lens from Canada (pp. 169-183). Bristol, England: Multilingual Matters.

Goh, Keng Swee and The Education Study Team. (1979). Report on the Ministry of Education 1978. Singapore: Ministry of Education.

Government of Canada. (2017). Budget 2017: Building a Strong Middle Class, 280. Retrieved from https://www.budget.gc.ca/2017/docs/plan/budget-2017-en.pdf

Government of Canada. (2018). Delivering on Truth and Reconciliation Commission Calls to Action. Retrieved from https://www.aadncaandc.gc.ca/eng/1524494530110/1524494579700

Government of Canada. (2019). Co-development of a national First Nations, Inuit and Métis languages act. Retrieved from https://www.canada.ca/en/canadianheritage/campaigns/indigenous-languages-legislation.html 
Hobson, J., Lowe, K., Poetsch, S., \& Walsh, M. (2010). Re-awakening languages: Theory and practice in the revitalisation of Australias Indigenous languages. Sydney: Sydney University Press.

Hornberger, N. H. (2008). Introduction: Can schools save Indigenous languages? Policy and practice on four continents. In N. H. Hornberger (Ed.), Can Schools Save Indigenous Languages? Policy and Practice on Four Continents (pp. 1-12). London, UK: Palgrave Macmillan.

Indian Act / Loi sur les Indiens, R.S.C. 1985, c. I-5 (2017). Retrieved from https://lawslois.justice.gc.ca/eng/acts/i-5/

Indigenous Services Canada. (2019). Kindergarten to grade 12 education. Retrieved from https://www.sac-isc.gc.ca/eng/1100100033676/1531314895090

LeClaire, N., \& Cardinal, G. (1998). Alberta Elders' Cree dictionary/alperta ohci kehtehayak nehiyaw otwestamâkewasinahikan. (E. Waugh, Ed.). Edmonton, AB: University of Alberta Press.

Legacy of Hope Foundation. (2014). Hope and healing: The legacy of the Indian residential school system. Ottawa, ON: Legacy of Hope Foundation.

Lewis, M. P., \& Simons, G. F. (2010). Assessing endangerment: Expanding Fishman's GIDS. Revue Roumaine de Linguistique, 55(2), 103-120. https://doi.org/10.1039/C6CP00978F

McCue, H. A. (2011). Education of Indigenous peoples in Canada. In The Canadian Encyclopedia. Retrieved from https://www.thecanadianencyclopedia.ca/en/article/aboriginal-people-education

McIvor, O. (2005). Building the nests: Indigenous language revitalization in Canada through early childhood immersion programs. Master's theses, University of Victoria, BC, Canada. ProQuest Dissertations Publishing, MRo2092.

McIvor, O. \& McCarty, T. (2016). Indigenous bilingual and revitalization-immersion education in Canada and the USA. In O. García et al. (eds.), Bilingual and Multilingual Education, Encyclopedia of Language and Education, pp. 1-17. Springer International Publishing: Switzerland. DOI 10.1007/978-3-319-02324-3_34-1

McIvor, O., Rosborough, T., \& McGregor, C. (2018). Lighting a fire: Community-based Indigenous language teacher education. In P. Whitinui, C. Rodriguez, \& O. McIvor, (Eds.). Promising practices in Indigenous teacher education, pp. 189-204. Springer: Singapore.

McIvor, O., Rosborough, T., \& McGregor, C. (2017). Language teacher education: Building a new generation of "language warriors” In Q'um Q'um Xiiem J. Archibald \& J. Hare (Eds.). Learning, knowing and sharing: Celebrating successes in K-12 Aboriginal Education in British Columbia, pp. 15-27. Office of Indigenous Education/Indigenous Education Institute of Canada, UBC \& BC Principals' \& Vice-Principals' Association.

Michel, K. A. (2012). Trickster's path to language transformation: Stories of Secwepemc immersion from Chief Atahm School. University of British Columbia, BC, Canada. https://doi.org/10.14288/1.0105178

Milloy, J. S. (1999). A national crime: The Canadian government and the residential school system, 1879 to 1986. Winnipeg, MB: University of Manitoba Press.

National Indian Brotherhood. (1972). Indian Control of Indian Education. Ottawa, ON: Assembly of First Nations. Retrieved from http://www.oneca.com/IndianControlofIndianEducation.pdf

Nisga'a final agreement, S.C. 2000, c. 7 (2003). Retrieved from https://lawslois.justice.gc.ca/eng/acts/N-23.3/ 
Nisga'a Lisims Government. (1998). Understanding the Nisga'a Treaty. Retrieved from http://www.nisgaanation.ca/understanding-treaty

Nunavut Department of Education. (2007). Inuit Qaujimajatuqangit: Education framework for Nunavut curriculum. Iqaluit, NU: Nunavut Department of Education, Curriculum and School Services Division. Retrieved from https://www.gov.nu.ca/sites/default/files/files/Inuit Qaujimajatuqangit ENG.pdf

Office of the Auditor General of Canada. (2013). Report of the Auditor General of Canada to the Legislative Assembly of Nunavut - 2013 Education in Nunavut. Ottawa, ON. Retrieved from http://www.oag-bvg.gc.ca/internet/docs/nun_201311_e_38772.pdf

Office of the Auditor General of Canada. (2018). Spring reports of the Auditor General of Canada to the Parliament of Canada: Report 5 - socio-economic gaps on First Nations reserves - Indigenous Services Canada. Retrieved from http://www.oagbvg.gc.ca/internet/English/parl_oag_201805_05_e_43037.html

Platt, J. T. (1982). Bilingual language policies in a multilingual nation: Singapore. Australian Review of Applied Linguistics, 5, 17-20.

Republic of the Philippines, Department of Education. (2009, July 14). Institutionalizing mother tongue-based multilingual education (MLE). Manila: Author.

http://mlephil.wordpress.com/2009/07/18/deped-order-no-74-s-2009/.

Republic of the Philippines, Department of Education. (2013, July 12). Department of Education adds 7 more languages in mother tongue-based education.

http://www.deped.gov.ph/index.php/newsupdates/

updates/updates-learners/386-deped-adds-7-more-languages-in-mother-tonguebasededucation.

Richards, M., \& Burnaby, B. (2008). Restoring Aboriginal languages: Immersion and intensive program models in Canada. In T. Williams Fortune \& D. J. Tedick (Eds.), Pathways to multilingualism: Evolving perspectives on immersion education (pp. 221-241). Clevedon, UK: Multilingual Matters Ltd.

Royal Government of Cambodia, Ministry of Education, Youth and Sport. (2015). Multilingual Education National Action Plan, 2015-2018. Phnom Penh: Author.

Statistics Canada. (2011). 2011 Census of Canada: Topic-based tabulations: Language spoken most often at home. (Catalogue no. 98-314-XCB2011042). Ottawa, ON. Retrieved from https://www 12.statcan.gc.ca/census-recensement/2011/dp-pd/tbt-tt/Rpeng.cfm? $\mathrm{LANG}=\mathrm{E} \& \mathrm{APATH}=3 \& \mathrm{DETAIL}=0 \& \mathrm{DIM}=0 \& \mathrm{FL}=\mathrm{A} \& \mathrm{FREE}=0 \& \mathrm{GC}=0 \& \mathrm{G}$ $\mathrm{ID}=0 \& \mathrm{GK}=0 \& \mathrm{GRP}=1 \& \mathrm{PID}=103089 \& \mathrm{PRID}=10 \& \mathrm{PTYPE}=101955 \& \mathrm{~S}=0 \& \mathrm{SHOWAL}$ $\mathrm{L}=0 \& \mathrm{SUB}=0 \& \mathrm{Temporal}=2011 \& \mathrm{THEME}=90 \& \mathrm{VID}=0 \& \mathrm{VNAMEE}=\& \mathrm{VNAMEF}$

Statistics Canada. (2017a). Census in Brief: The Aboriginal languages of First Nations people, Métis and Inuit. Statistics Canada Census of Population, 2016. (Catalogue no. 98-200X2016022). Ottawa, ON. Retrieved from http://www 12.statcan.gc.ca/censusrecensement/2016/as-sa/98-200-x/2016022/98-200-x2016022-eng.cfm

Statistics Canada. (2017b). Focus on geography series, 2016 census: Nunavut. Retrieved from https://www 12.statcan.gc.ca/census-recensement/2016/as-sa/fogs-spg/Facts-PREng.cfm? TOPIC $=9 \& \mathrm{LANG}=\mathrm{Eng} \& \mathrm{GK}=\mathrm{PR} \& \mathrm{GC}=62$

Thorstenson, C., Hanna, D., \& Callison, C. (2006). Aboriginal People and the Law in British Columbia. Retrieved from http://www.lss.bc.ca/assets/pubs/aboriginalPeopleAndTheLawInBC.pdf

Treaty 5 between her Majesty the Queen and the Saulteaux and Swampy Cree tribes of Indians at Beren's River and Norway House with adhesions, September 24 1875, Cat. No.: R33-0557, IAND Publication No. QS-0573-000-EE-A-1, The Queen's Printer 
(1969). Retrieved from https://www.aadncaandc.gc.ca/eng/1100100028699/1100100028700

Truth and Reconciliation Commission of Canada. (2015). Honouring the truth, reconciling for the future: Summary of the final report of the Truth and Reconciliation Commission of Canada. Retrieved from https://nctr.ca/reports2.php

UNESCO. (2017). Atlas of the world's languages in danger. Retrieved from http://www.unesco.org/new/en/culture/themes/endangered-languages/atlas-oflanguages-in-danger/

United Nations. (2015). Transforming our world: The 2030 agenda for sustainable development, United Nations General Assembly 7oth sess. UN doc. A/RES/70/1. https://doi.org/10.1007/s 13398-0 14-0 173-7.2

United Nations Declaration on the Rights of Indigenous Peoples (UNDRIP), General Assembly 61st session, UN doc A/61/L.67 (2007). https://doi.org/10.1017/So940739107070270

Wabi Benais Mistatim Equay (Cynthia Bird). (2018, April). The numbered treaties. Canada's History. Retrieved from https://www.canadashistory.ca/explore/settlementimmigration/the-numbered-treaties

Yukon Schools. (2018). Tukon First Nations Languages. Retrieved from http://1ss.yukonschools.ca/yukon-first-nations-languages.html Zuckerman, G. (in press, 2019). Revivalistics, cross-fertilization and wellbeing: Awakening Hebrew and other sleeping beauty languages. New York: Oxford University Press.

\section{About the Authors}

Onowa McIvor is maskékow-ininiw (Swampy Cree) and Scottish-Canadian from Treaty 5 territory. Her maternal family is from kinosao sipi (Norway House First Nation) and Pimicikamak (Cross Lake) in northern Manitoba, and her paternal family were settlers in southern Saskatchewan. Onowa currently resides in SENĆOFEN and Lekwungen speaking territories on southern Vancouver Island in BC. Dr. McIvor is a lifelong adult learner of her mother tongue nehinaw/nehiyaw/nehithaw. Dr. McIvor is an Associate Professor in the Department of Indigenous Education at the University of Victoria and coleads the NETOLNEW_Research Partnership Grant, a six-year SSHRC project working to understand and enhance Indigenous adults' contributions to reviving Indigenous languages in Canada. Her broader research focuses on Indigenous language-in-education policy, various aspects of additional language learning and language education; language learning assessment and links between language use, health and well-being. However, her most important job is raising her daughters with the help of her family.

Jessica Ball, MPH, PhD, is a Professor in the School of Child and Youth Care at the University of Victoria in Canada. She is a third generation, English-speaking Canadian of Irish and English settler descent. Her program of research uncovers processes that produce marginalization and inequities for Indigenous and minoritized young children in Canada and the Asia-Pacific region. Her recent work evaluates the impacts of colonial and innovative, post-colonial language-in-education polices in ASEAN countries. Her scholarship seeks to inform new and revised policies, curricula and teacher education that includes the perspectives of minority language speakers including parents and children. 